\title{
KAUSALITAS GRANGER PDRB TERHADAP KESEMPATAN KERJA DI PROVINSI DATI I JAWA TENGAH
}

\author{
Daryono Soebagiyo \\ Fakultas Ekonomi Universitas Muhammadiyah Surakarta \\ E-mail: dsoebagyo@yahoo.com
}

\begin{abstract}
This research conducted to know the relation of causality between Regional Gross Domestic Products (PDRB) and level of employment. Research method which applied is Granger causality test. Then to get estimation result, done testing stationerity, integration degree testing by using ADF (Augmented Dickey Fuller), and testing cointegration by using ADF. Data in the research is time series data from year 1979 up to 2004. Analysis result gives conclusion that found unidirectional causality relation from Regional Gross Domestic Product (PDRB) to employment level.
\end{abstract}

Keywords: PDRB, employment, granger causality

\section{PENDAHULUAN}

Pertumbuhan ekonomi yang tinggi dan proses pembangunan berkelanjutan merupakan kondisi utama bagi kelangsungan perkembangan ekonomi daerah. Jumlah penduduk yang terus bertambah memiliki implikasi kebutuhan ekonomi masyarakat juga bertambah. Oleh sebab itu dibutuhkan penambahan pendapatan setiap tahunnya. Hal ini hanya bisa didapat melalui peningkatan output agregat (barang dan jasa) atau Produk Domestik Bruto (PDB) setiap tahun. Di dalam pengertian ekonomi makro, pertumbuhan ekonomi adalah penambahan PDB yang berarti juga penambahan Pendapatan Nasional (Tambunan, 2001: 38).

Perkembangan Produk Domestik Regional Bruto (PDRB) di Jawa Tengah dari tahun 1979 sampai 2004 terus mengalami kenaikan. Pada tahun 1979 besarnya PDRB adalah
Rp.2.845.575.690.000 dan terus meningkat, hingga pada tahun 2002 PDRB mencapai Rp. 156.418.300.460.000 yang berarti terjadi kenaikan sebesar Rp. 20.286.820.300.000 dibanding tahun 2001. Tingkat PDRB tertinggi dicapai pada tahun 2004 yaitu sebesar Rp 193.435.263.050.000. Kenaikan tersebut beralasan mengingat kondisi ekonomi pada tahun tersebut mengalami perbaikan di berbagai sektor.

Sedangkan dari gambaran jumlah penduduk Propinsi Dati I Jawa Tengah berdasarkan Survei Sosial Ekonomi Nasional (SUSENAS), pada tahun 2000 tercatat sebesar 30,78 juta jiwa atau sekitar $15 \%$ dari total penduduk Indonesia, dan menempati urutan ketiga dari seluruh propinsi di pulau Jawa. Jumlah penduduk Jawa Tengah di tahun 2001 mengalami peningkatan hingga mencapai 31,73 juta jiwa. Sejalan peningkatan jumlah penduduk, muncul tenaga kerja 
terampil, sungguhpun belum bisa menggunakan ketrampilannya. Padahal mereka merupakan potensi SDM yang sangat dibutuhkan dalam proses pembangunan guna menyongsong era globalisasi. Hasil SUSENAS juga memperlihatkan bahwa total tenaga kerja di Jawa Tengah tahun 2000 mencapai 14,49 juta jiwa atau turun sebesar $0,51 \%$ dibandingkan tahun sebelumnya.

Kebutuhan SDM potensial mengakibatkan peningkatan produktivitas bila dibarengi dengan peningkatan mutu pendidikan yang memadai. SDM yang terdidik makin banyak pada usia kerja baik yang sudah bekerja atau belum bekerja di Jawa Tengah menurut SUSENAS tahun 20000 mencapai 15.129.122 jiwa, pendidikan tertinggi yang dicapai adalah tamatan SD 5.675.927 jiwa (Daryono, Chuzaimah, Setyowati; 2003).

Dari latar belakang tersebut dapat dirumuskan masalah penelitian ini yaitu menganalisis uji kausalitas Granger PDRB terhadap kesempatan kerja di Provinsi Dati I Jawa Tengah dengan data runtut waktu (time series) dari tahun 1979 sampai dengan tahun 2004".

\section{LANDASAN TEORI}

\section{Pengertian Produk Domestik Regional Bruto (PDRB)}

Keberhasilan pembangunan ekonomi daerah baik yang dilakukan oleh pemerintah maupun masyarakat swasta dalam rangka peningkatan kesejahteraan penduduknya dapat dinilai dari besarnya tingkat pertumbuhan Produk Domestik Regional Bruto (PDRB).
Produk Domestik Regional Bruto adalah nilai dari seluruh produksi nilai barang dan jasa yang dihasilkan oleh berbagai aktivitas ekonomi dalam suatu daerah, dalam kurun waktu tertentu, biasanya tiap tahun. PDRB merupakan suatu indikator yang penting untuk mengetahui tingkat keberhasilan pembangunan daerah yang telah dilaksanakan dan sekaligus berguna untuk menentukan arah pembangunannya di masa yang akan datang. PDRB juga secara tidak langsung merupakan salah satu indikator yang dapat digunakan untuk menilai kemampuan daerah dalam mengelola sumber daya alam yang dimilikinya.

PDRB pada hakekatnya mengambarkan tingkat kegiatan perekonomian suatu daerah, baik yang dilakukan oleh masyarakat, swasta, maupun pemerintah dalam suatu periode tertentu, meliputi seluruh hasil produksi atau output yang diciptakan oleh suatu daerah. Sehingga PDRB secara tidak langsung dapat digunakan sebagai indikator dalam menilai hasil kegiatan pembangunan ekonomi daerah secara keseluruhan (Daryono, 1994: 19-20)

Pertumbuhan ekonomi daerah dari tahun ke tahun dapat dilihat melalui besaran PDRB baik berdasarkan harga berlaku maupun berdasarkan harga konstan. PDRB atas dasar harga berlaku menggambarkan nilai tambah dan barang dan jasa yang menggunakan harga pada setiap tahun, sedangkan PDRB atas dasar harga konstan menunjukkan nilai tambah barang dan jasa yang dihitung menggunakan harga pada tahun tertentu sebagai dasar, yang menunjukkan pertumbuhan ekonomi daerah secara riil, karena telah dikurangi atau diperhitungkan faktor inflasi. 


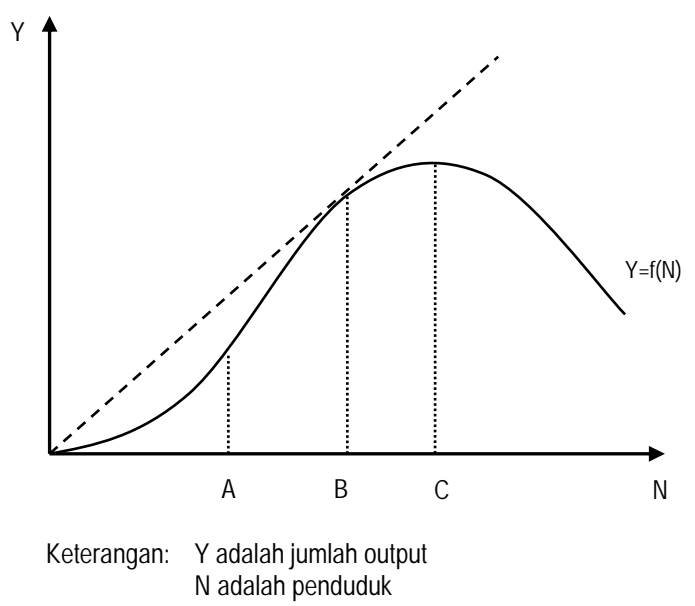

Gambar 1. Penduduk sebagai Beban dan Modal Pembangunan

Peningkatan Produk Domestik Regional Bruto secara langsung mempengaruhi peningkatan pertumbuhan ekonomi suatu negara atau suatu daerah yang diwujudkan dalam suatu kegiatan pembangunan. Dengan adanya kegiatan pembangunan yang merupakan kegiatan ekonomi suatu daerah atau negara, akan membawa harapan baru bagi penduduknya yang diwujudkan dalam peningkatan penyerapan tenaga kerja. Dalam pembahasan lebih mendalam hal ini terkait dengan teori penduduk optimal.

Konsep penduduk optimal pertama kali diperkenalkan oleh John Stuart Mill, sungguhpun Mill sadar bahwa jumlah optimal hanya dapat tercapai dalam suatu masyarakat yang warganya dapat diatur secara paksa. Hubungan antara jumlah penduduk optimal adalah jumlah penduduk yang menghasilkan produksi perkapita yang tinggi. Jumlah tersebut dikatakan optimal dalam arti tidak ada perubahan baik dalam jumlah dan mutu sumber daya yang tidak dapat diperbaharui maupun tersedianya modal fisik. Pengertian produksi tersebut tidak harus terbatas pada baju atau mobil, pendidikan, kebersihan ling- kungan, tetapi dapat pula mencakup komoditas barang yang diproduksi.

\section{Penduduk dalam Teori Ekonomi}

Perhatian ekonom pada variabel kependudukan tidak pernah putus, walaupun tingkatnya berfluktuasi dan perhatian itupun sering terbatas pada variabel ketenagakerjaan. Pada model Klasik variabel pekerja mempunyai peranan yang penting dalam pertumbuhan ekonomi. Perhatian ini berlangsung terus sampai zamannya Keynes.

Pada masa Keynes, employment masih menjadi salah satu perhatian utama analisis ekonomi. Keynes masih menganggap penting segi penawaran. Keynes membahas segi permintaan (bukan penawaran) secara mendalam karena segi penawaran telah dibahas dengan mendalam oleh para ekonom saat itu. Lebih lanjut; Keynes berpendapat bahwa segi permintaan tersebut terutama amat penting untuk masyarakat kaya dalam studi ini analisis Keynes mendapat porsi relatif lebih besar. Pemberian porsi ini dimaksudkan untuk menjernihkan penafsiran teori Keynes 
seperti yang tertulis dalam General Theory of Employment, Interest and Money.

Variabel kependudukan dalam teori Keynes yang disederhanakan menjadi variabel ketenagakerjaan mulai muncul dalam analisis lagi di tahun 1930-an Pada saat itu, di Amerika dan Inggris terjadi krisis employment. Banyak orang yang ingin bekerja tetapi tidak mendapatkan pekerjaan, pada hal mereka sebenarnya mampu bekerja. Persediaan barang dan jasa amat sedikit, walaupun sebenarnya orang mampu menghasilkannya. Mekanisme pasar telah mengakibatkan tak satupun pihak yang merasa diuntungkan untuk mulai berproduksi, hal itu disebut "paradoks poverty in the midst of plenty"

Kemudian Hicks dan Hansen mencoba menafsiri teori Keynes dalam baju IS-LM. Di sini pasar pekerja hilang dari analisis. Mulai saat itu pasar analisis ekonom (khususnya ekonomi makro) kehilangan minat pada masalah kependudukan. Kerangka IS-LM sempat mendominasi buku teks Ekonom makro hingga awal dasawarsa tujuh puluhan. Masalah kependudukan seakan-akan bukan lagi bidang yang perlu ditekuni oleh ekonom.

Ketika ekonom negara maju mulai tertarik pada perekonomian negara berkembang (waktu itu disebut under-developed countries) masalah kependudukan kembali muncul dalam analisis ekonomi. Pada dasawarsa lima puluhan jumlah penduduk merupakan suatu topik baru bagi para ekonom yang menspesialisasi pada kasus negara berkembang. Muncul mata kuliah economics for under-developend countries; untuk membedakan dari ekonomi mikro yang berorientasi pada kesejahteraan pada masyarakat kaya. Nama mata kuliah ini kemudian direvisi dan menjadi bentuk yang kita kenal dengan development economics.
Sejak pertengahan dasawarsa enam puluhan, dan makin kuat sejak dasawarsa tujuh puluhan; perhatian bergeser dari jumlah ke mutu penduduk. Di Indonesia masalah kualitas penduduk akhir-akhir ini makin banyak mendapat perhatian. Indonesia menginginkan mengubah jumlah penduduk dari beban menjadi modal pembangunan.

\section{Hubungan antara Pertumbuhan Ekonomi dan Tingkat Kesempatan Kerja}

Besarnya tingkat kesempatan kerja dari suatu wilayah atau negara tertentu akan sangat tergantung pada faktor sosial ekonomi dari wilayah atau negara tersebut, faktor-faktor tersebut antara lain tingkat pertumbuhan ekonomi, jumlah penduduk dan tingkat kesempatan kerja

Menurut pendekatan Gainful Worker, beranggapan bahwa dalam perekonomian suatu negara atau daerah, tingkat keberhasilan yang dicapai dapat diukur melalui luasnya kesempatan kerja yang dapat diciptakan atau dapat dihitung dari jumlah orang yang berhasil mendapatkan pekerjaan. Pendekatan ini didasarkan pada kegiatan yang bisa dilakukan dalam kurun waktu yang relatif panjang (misal 6 bulan atau 12 bulan) oleh seseorang dan yang memberikan pendapatan kepadanya

\section{Penelitian Terdahulu}

Penelitian yang membahas tentang PDRB dan tingkat kesempatan kerja telah dilakukan oleh peneliti luar negeri maupun peneliti di Indonesia sendiri. Sehingga penelitian ini bukan satu-satunya yang mengupas tentang masalah PDRB terhadap tingkat kesempatan kerja. Sugiyono (2005) dalam penelitiannya mengenai "Analisis Kausalitas antar PDRB dan Tingkat Pengerjaan di Jawa Tengah 
Tahun 1978 sampai 2003", menggunakan alat analisis Uji Kausalitas Granger. Hasil penelitian membuktikan bahwa Produk Domestik Bruto mempengaruhi tingkat pengerjaan di Jawa Tengah pada $\alpha=0,10$.

Kusumawati (1998) dalam penelitiannya mengenai "Pengaruh Pertumbuhan Ekonomi terhadap Kesempatan Kerja di Jawa Tengah 1976 sampai 1996", menggunakan alat analisis regresi linear berganda. Hasil analisis yang diperoleh dalam penelitian ini adalah variabel produk domestik regional bruto (PDRB) mempengaruhi kesempatan kerja di Jawa Tengah pada $\alpha=0,05$.

Daryono Soebagiyo et. al (2005), meneliti tentang "Analisis pengaruh Kesempatan Kerja, Tingkat Beban/Tanggungan dan Pendidikan Terhadap Pengangguran di Propinsi Dati I Jawa Tengah" Dalam analisisnya, diperoleh hasil bahwa semakin tinggi tingkat pendidikan seseorang, hubungannya dengan rasio beban tanggungan tidak memiliki pengaruh terhadap tingkat pengangguran baik untuk jangka pendek maupun jangka panjang. Sedang unuk pengangguran masa lalu tidak memiliki pengaruh signifikan terhadap pengangguran saat ini.

\section{METODE PENELITIAN}

\section{Jenis dan Sumber Data}

Data yang digunakan adalah data sekunder. Berbentuk data time series dalam rentang waktu 25 tahun, dari tahun 1979 sampai 2004. Data sekunder yang dikumpulkan meliputi data PDRB dan tingkat kesempatan kerja, dari Publikasi Badan Pusat Statistik (BPS) Jawa Tengah.

\section{Definisi Operasional Variabel}

Variabel yang digunakan dalam uji Kausalitas Granger adalah:

a. Produk Domestik Regional Bruto (PDRB) PDRB adalah nilai akhir barang dan jasa yang diproduksi dalam masyarakat selama satu periode tertentu, biasanya satu tahun. Variabel ini diukur dalam satuan jutaan rupiah pertahun (Sukirno, $2002: 10$ ).

b. Tingkat Kesempatan Kerja

Tingkat Kesempatan Kerja adalah banyaknya pencari kerja yang ditempatkan menurut lapangan usaha di Jawa Tengah. Variabel ini diukur dalam jumlah orang pertama.

\section{Metode Analisis Data}

Untuk menguji secara empirik hipotesis ini menggunakan analisis Kausalitas Granger antara dua variabel. Uji Kausalitas Granger merupakan sebuah metode untuk mengetahui di mana suatu variabel dependen (variabel tidak bebas) dapat dipengaruhi oleh variabel lain (variabel independen) dan di sisi lain variabel independen tersebut dapat menempati posisi dependen variabel. Hubungan seperti ini disebut hubungan kausal atau timbal balik. Maka variabel Produk Domestik Regional Bruto (PDRB) dan tingkat kesempatan kerja diformulasikan di bawah ini

$$
\begin{aligned}
& \mathrm{Xt}=\sum_{i=1}^{m} \alpha_{\mathrm{i}} \mathrm{X}_{\mathrm{t}-\mathrm{i}}+\sum_{\mathrm{j}=1}^{\mathrm{m}} \beta_{\mathrm{j}} \mathrm{Y}_{\mathrm{t}-\mathrm{j}}+\mathrm{U}_{\mathrm{t} 1} \\
& \mathrm{Yt}=\sum_{i=1}^{m} \lambda_{\mathrm{i}} \mathrm{X}_{\mathrm{t}-\mathrm{i}}+\sum_{\mathrm{j}=1}^{\mathrm{m}} \delta_{\mathrm{j}} \mathrm{Y}_{\mathrm{t}-\mathrm{j}}+\mathrm{U}_{\mathrm{t} 2}
\end{aligned}
$$

Keterangan:

$\mathrm{Xt}=$ PDRB Provinsi Jawa Tengah (dalam jutaan rupiah) 
Yt = Kesempatan kerja Jawa Tengah (dalam orang)

$\mathrm{m}=$ Jumlah lag

$\mathrm{U}_{\mathrm{t} 1}, \mathrm{U}_{\mathrm{t} 2}=$ Variabel pengganggu

$\alpha, \beta, \lambda, \delta=$ Koefisien masing-masing variabel

diasumsikan bahwa gangguan $\mathrm{u}_{\mathrm{t} 1}$ dan $\mathrm{u}_{\mathrm{t} 2}$ tidak berkorelasi

Pada data urut (time series) sering terjadi hubungan korelasi yang langsung (spurious) karena masalah data yang tidak stasioner dan tidak terkointegrasi. Oleh karena itu tahapan umum dalam uji Kausalitas Granger adalah (Gujarati, Basic Econometrics)

1. Uji Stasioneritas terhadap dua variabel (PDRB dan Tingkat Kesempatan Kerja) dengan menggunakan uji unit root Dickey Fuller.

2. Apabila ternyata kedua variabel stasioner maka dilanjutkan ke uji Kausalitas Granger pada data asli. Apabila salah satu kedua variabel tidak stasioner, maka akan dilakukan pengujian untuk mengetahui apakah kedua variabel terkointegrasi ataukah tidak.

3. Apabila ternyata kedua variabel terkointegrasi, maka akan dilakukan uji Kausalitas Granger pada data asli. Apabila tidak terkointegrasi, data yang tidak stasioner akan distasionerkan dengan pembedaan (differencing) baru kemudian dilakukan uji Kausalitas Granger pada data yang stasioner.

Langkah-langkah pengujian pada penelitian ini:

\section{Uji Stasioner}

Uji stasioner bertujuan untuk mengetahui apakah data stasioner dapat langsung diestimasi ataukah tidak stasioner karena mengandung unsur trend (random walk) yang perlu dilakukan penanganan tertentu yaitu dengan jalan membedakan. Jika sebagaimana umumnya data tidak stasioner, maka proses differencing harus dilakukan beberapa kali sehingga tercapai data yang stasioner.

Suatu data urut waktu dikatakan stasioner apabila memenuhi syarat-syarat sebagai berikut (Gujarati, 2003 : 797):

Rata-rata : $\quad \mathrm{E}\left(\mathrm{Y}_{\mathrm{t}}\right)=\mu$ (rata-rata konstan)

Variance: $\operatorname{Var}\left(\mathrm{Y}_{\mathrm{t}}\right)=\mathrm{E}\left(\mathrm{Y}_{\mathrm{t}}-\mu\right)^{2}=\sigma^{2}$

Covariance : $\mathrm{K}=\mathrm{E}\left[\left(\mathrm{Y}_{\mathrm{t}}-\mu\right)\left(\mathrm{Y}_{\mathrm{t}}+\mathrm{K}-\mu\right)\right]$ atau covarian antara dua periode bergantung pada jarak waktu antara dua periode waktu tersebut dan tidak tergantung pada waktu dimana covarian dihitung.

Data urut waktu yang stasioner pada dasarnya ada gerakan yang sistematis, artinya perkembangan nilai variabel disebabkan faktor random yang stokastik. Terdapat beberapa metode untuk menguji stasioneritas, yang populer adalah uji unit root Dickey Fuller (DF) dan Augmented Dickey Fuller (ADF).

Untuk uji Dickey Fuller (DF) dilakukan dengan tiga alternatif model seperti berikut ini (Gujarati, 1995 : 720):

1. $\Delta \mathrm{Y}_{\mathrm{t}}=\delta \mathrm{Y}_{\mathrm{t}-1}+\mathrm{U}_{\mathrm{t}}$

atau

2. $\Delta \mathrm{Y}_{\mathrm{t}}=\beta_{1}+\delta \mathrm{Y}_{\mathrm{t}-1}+\mathrm{U}_{\mathrm{t}}$ atau

atau

3. $\Delta \mathrm{Y}_{\mathrm{t}}=\beta_{1}+\beta_{2}-\delta \mathrm{Y}_{\mathrm{t}-1}+\mathrm{U}_{\mathrm{t}}$

Sedangkan uji Augmented Dickey Fuller (ADF) yang merupkan perluasan dari uji DF memiliki tiga alternatif model sebagai berikut: 
1. $\Delta \mathrm{Y}_{\mathrm{t}}=\delta \mathrm{Y}_{\mathrm{t}-1}+\alpha_{\mathrm{i}} \sum_{i=1}^{m} \Delta \mathrm{Y}_{\mathrm{t}-\mathrm{i}}+\mathrm{U}_{\mathrm{t}}$

atau

2. $\Delta \mathrm{Y}_{\mathrm{t}}=\beta_{1}+\delta \mathrm{Y}_{\mathrm{t}-1}+\alpha_{\mathrm{i}} \sum_{i=1}^{m} \Delta \mathrm{Y}_{\mathrm{t}-\mathrm{I}}+\mathrm{U}_{\mathrm{t}} \ldots$

atau

3. $\Delta \mathrm{Y}_{\mathrm{t}}=\beta_{1}+\beta_{2 \mathrm{t}}-\delta \mathrm{Y}_{\mathrm{t}-1}+\alpha_{\mathrm{i}} \sum_{i=1}^{m} \Delta \mathrm{Y}_{\mathrm{t}-\mathrm{i}}+\mathrm{U}_{\mathrm{t}}$

Untuk mengetahui data stasioner atau tidak dapat dilihat dengan membandingkan antara nilai statistik DF atau ADF dengan nilai koefisiennya. Jika nilai absolut statistik DF atau ADF lebih besar dari nilai koefisiennya maka data menunjukkan stasioneritas dan jika sebaliknya maka data tidak stasioner.

\section{Uji Kointegrasi}

Dua atau lebih variabel urut waktu dikatakan terkointegrasi apabila masing-masing variabel tersebut memiliki pola trend yang sama sehingga ketika variabel-variabel tersebut diregresi, trend di dalam masing-masing variabel menjadi saling menghilangkan (Utomo, 2000: 59).

Untuk menguji apabila PDRB dan tingkat kesempatan kerja merupakan variabel yang terkointegrasi digunakan uji Engle Granger (EG) dan uji Augmented Engle Granger (AEG). Uji EG dan AEG dilakukan dengan cara sebagai berikut:

a. Meregres $\mathrm{PDRB}_{\mathrm{t}}=\beta_{1}+\beta_{2} \mathrm{TP}_{\mathrm{t}}+\hat{\mathrm{U}}_{\mathrm{t}}$, selanjutnya menghitung $\hat{U}_{t}$ dengan formula $\hat{U}_{t}=\mathrm{PDRB}_{\mathrm{t}}-\beta_{1}-\beta_{2} \mathrm{TP}_{\mathrm{t}}$

b. Kemudian dilakukan uji stasioner pada $\hat{\mathrm{U}}_{\mathrm{t}}$, pada uji EG, stasioner $\hat{\mathrm{U}}_{\mathrm{t}}$, diuji dengan Dickey Fuller dengan formulasi: $\Delta \hat{\mathrm{U}}_{\mathrm{t}}=\delta \hat{\mathrm{U}}_{\mathrm{t}-1}+\epsilon_{\mathrm{t}}$

Sedangkan pada uji AEG, stasioner $\hat{\mathrm{U}}_{\mathrm{t}}$ diuji dengan uji Augmented Dickey Fuller dengan formulasi: $\Delta \hat{\mathrm{U}}_{\mathrm{t}}=\delta \hat{\mathrm{U}}_{\mathrm{t}-1}+$ $\alpha \Delta \hat{\mathrm{U}}_{\mathrm{t}-1}+\epsilon_{\mathrm{t}}$

Apabila $\hat{U}$ stasioner $(\delta \neq 0)$ berarti PDRB dan KK merupakan dua variabel urut waktu yang berintegrasi, uji baru ADF pada $\hat{U}_{t}$ akan dilakukan apabila pada uji DF $\hat{U}_{t}$ tidak stasioner.

Uji kointegrasi adalah uji yang digunakan untuk mengetahui hubungan yang stabil dalam jangka panjang. Apabila tidak terdapat kointegrasi antara variabel maka tidak terdapat keterkaitan hubungan dalam jangka panjang.

\section{Uji Derajat Kointegrasi}

Merupakan analisis yang dilakukan karena data belum mencapai stasioneritas maupun belum terkointegrasi maka perlu dilakukan pada uji Derajat Integrasi untuk penstasioneran data agar diperoleh hasil regresi yang tidak langsung. Penstasioneran data PDRB dan tingkat kesempatan kerja dilakukan dengan melakukan uji DF maupun uji ADF pada perbedaan tingkat satu atau derajat integrasi satu (first difference)

\section{Uji Kausalitas Granger}

Uji Kausalitas Granger pada dasarnya mengasumsikan bahwa informasi yang relevan untuk memprediksi variabel PDRB dan tingkat kesempatan kerja adalah hanya terdapat pada kedua data urut waktu dari kedua variabel tersebut.

Diasumsikan bahwa gangguan $\mathrm{u}_{\mathrm{t} 1}$ dan $\mathrm{u}_{\mathrm{t} 2}$ tidak berkorelasi 
Hasil-hasil regresi kedua bentuk model ini akan menghasilkan empat kemungkinan mengenai nilai koefisien-koefisien yaitu:

1. $\sum_{\mathrm{i}=1}^{\mathrm{m}} \alpha \mathrm{i} \neq 0$ dan $\sum_{\mathrm{j}=1}^{\mathrm{m}} \delta \mathrm{j}=0$, maka terdapat kausalitas satu arah dari variabel kesempatan kerja terhadap variabel PDRB di Jawa Tengah.

2. $\sum_{\mathrm{j}=1}^{\mathrm{m}} \alpha \mathrm{i}=0 \mathrm{dan} \sum_{\mathrm{j}=1}^{\mathrm{m}} \delta \mathrm{j} \neq 0$, maka terdapat kausalitas satu arah dari variabel PDRB terhadap variabel kesempatan kerja di Jawa Tengah.

3. $\sum_{\mathrm{i}=1}^{\mathrm{m}} \alpha \mathrm{i}=0 \mathrm{dan} \sum_{\mathrm{j}=1}^{\mathrm{m}} \delta j=0$, maka tidak terdapat kausalitas baik antara variabel PDRB terhadap kesempatan kerja maupun antara variabel kesempatan kerja terhadap variabel PDRB di Jawa Tengah.

4. $\sum_{\mathrm{i}=1}^{\mathrm{m}} \alpha \mathrm{i} \neq 0 \mathrm{dan} \sum_{\mathrm{j}=1}^{\mathrm{m}} \delta \mathrm{j} \neq 0$, maka terdapat kausalitas dua arah baik antara variabel PDRB terhadap kesempatan kerja maupun antara variabel kesempatan kerja terhadap variabel PDRB di Jawa Tengah.

\section{ANALISIS DAN PEMBAHASAN}

\section{Perkembangan Produk Domestik Regio- nal Bruto}

Perkembangan Produk Domestik Regional Bruto dari tahun 1979 sampai dengan tahun 2004 terus mengalami peningkatan. Perkembangan terakhir pada tahun 2001 Produk Domestik Regional Bruto menunjukkan peningkatan sebesar $14,90 \%$. Sedang tahun 2004 Produk Domestik Regional Bruto menunjukkan peningkatan sebesar $11,26 \%$.
Kenaikan tersebut cukup beralasan mengingat kondisi ekonomi pada tahun tersebut mengalami perbaikan berbagai sektor. Data perkembangan PDRB dan Kesempatan Kerja di Dati I Jawa Tengah dapat dilihat dalam tabel 1 .

Tabel 1. Data PDRB dan Kesempatan Kerja Propinsi Dati I Jawa Tengah

\begin{tabular}{ccc}
\hline TAHUN & $\begin{array}{c}\text { PDRB } \\
\text { (Harga Konstan) } \\
\text { Dalam Juta } \\
\text { Rupiah }\end{array}$ & $\begin{array}{c}\text { KESEMPATAN } \\
\text { KERJA } \\
\text { Dalam Orang }\end{array}$ \\
\hline 1979 & 2845575,69 & 9571487 \\
1980 & 3741066,57 & 9881676 \\
1981 & 4994942,21 & 9549352 \\
1982 & 5726662,68 & 11179350 \\
1983 & 6966815,22 & 9966183 \\
1984 & 8111093,46 & 10636388 \\
1985 & 9177171,71 & 11351663 \\
1986 & 10575571,80 & 12573622 \\
1987 & 13593745,27 & 12571258 \\
1988 & 16422805,51 & 12982509 \\
1989 & 18692151,22 & 13106608 \\
1990 & 21689283,14 & 13424784 \\
1991 & 25980442,64 & 13544104 \\
1992 & 30200680,97 & 13611177 \\
1993 & 33978909,16 & 13632439 \\
1994 & 39303565,04 & 13765142 \\
1995 & 46586032,91 & 13462285 \\
1996 & 52505360,63 & 14262731 \\
1997 & 60296426,87 & 14128038 \\
1998 & 84610222,51 & 14186853 \\
1999 & 101509193,76 & 14621149 \\
2000 & 117782925,19 & 15764044 \\
2001 & 136131480,16 & 15066542 \\
2002 & 156418300,46 & 15154856 \\
2003 & 173852789,13 & 15124082 \\
2004 & 193435263,05 & 15528110 \\
\hline & & \\
\hline
\end{tabular}

Sumber: Kanwil BPS Propinsi Dati I Jawa Tengah 


\section{Perkembangan Tingkat Kesempatan Kerja}

Jumlah Kesempatan Kerja di Provinsi Dati I Jawa Tengah dari tahun 1979 sampai dengan tahun 2004 (lihat Tabel.1) mengalami fluktuasi. Kenaikan tertinggi pada tahun 1982 sebesar 17,07\%. Pada tahun 2001 terjadi penurunan hingga sebesar $-4,, 42 \%$. Sedangkan tahun 2002 kesempatan kerja mengalami peningkatan sebesar 0,59\%. Tahun 2003 kesempatan kerja mengalami penurunan sebesar -0,20\%. Tetapi di tahun 2004 kesempatan kerja mengalami kenaikan sebesar $2,67 \%$.

\section{Hasil Analisis Data}

\section{Uji Stasioner}

Uji Stasioneritas digunakan untuk mengetahui apakah data Produk Domestik Regional Bruto (PDRB) dan Tingkat Kesempatan Kerja (KK) telah stasioner. Pengujian ini dilakukan untuk menghindari adanya hasil regresi langsung pada data yang tidak sta- sioner. Dalam penelitian ini uji Stasioner menggunakan Augmented Dickey Fuller (ADF).

Berdasarkan tabel 2 dapat dilihat bahwa hasil pengolahan data dengan uji ADF menunjukkan variabel PDRB adalah stasioner. Stasioneritas variabel PDRB diperkuat pada model uji terbaik yaitu pada uji yang mempunyai nilai Akaike Information Criterion (AIC) minimum. Hal ini ditunjukkan pada model III dengan nilai ADF lebih besar (3,337178) dibandingkan nilai kritis MacKinnon value pada derajat kepercayaan $10 \%$ sebesar $(-3,277364)$, dengan nilai AIC minimum sebesar $(32,98196)$.

Berdasarkan tabel 3 dapat dilihat bahwa hasil pengolahan data dengan uji ADF menunjukkan variabel KK adalah tidak stasioner. Stasioneritas variabel KK diperkuat pada model uji terbaik yaitu pada uji yang mempunyai nilai Akaike Information Criterion (AIC) minimum. Hal ini ditunjukkan pada model III dengan nilai ADF lebih kecil $(-2,837492)$ dibandingkan nilai kritis

Tabel 2. Hasil Uji ADF Variabel PDRB

\begin{tabular}{llcr}
\hline ADF Model I & & & \\
AIC = 33,04599 & Dickey Fuller t-statistik & & 3,945547 \\
& MacKinnon critical value & $1 \%$ & $-2,692358$ \\
& & $5 \%$ & $-1,960171$ \\
& & $10 \%$ & $-1,607051$ \\
\hline ADF Model II & & & \\
AIC =33,13283 & Dickey Fuller t-statistik & & 3,495411 \\
& MacKinnon critical value & $1 \%$ & $-3,831511$ \\
& & $5 \%$ & $-3,029970$ \\
& & $10 \%$ & $-2,655194$ \\
\hline ADF Model III & & & \\
AIC =32,98196 & Dickey Fuller t-statistik & & 3,337178 \\
& MacKinnon critical value & $1 \%$ & $-4,532598$ \\
& & $5 \%$ & $-3,673616$ \\
& & $10 \%$ & $-3,277364$ \\
\hline
\end{tabular}


Tabel 3. Hasil Uji ADF Variabel KK

\begin{tabular}{llcr}
\hline ADF Model I & & & \\
AIC = 29,41784 & Dickey Fuller t-statistik & & 2,540965 \\
& MacKinnon critical value & $1 \%$ & $-2,664853$ \\
& & $5 \%$ & $-1,955681$ \\
& & $10 \%$ & $-1,608793$ \\
& & & \\
\hline ADF Model II & & & \\
AIC = 29,35500 & Dickey Fuller t-statistik & & $-1,421454$ \\
& MacKinnon critical value & $1 \%$ & $-3,737853$ \\
& & $5 \%$ & $-2,991878$ \\
& & $10 \%$ & $-2,635542$ \\
\hline ADF Model III & & & \\
AIC = 29,31618 & Dickey Fuller t-statistik & & $-2,837492$ \\
& MacKinnon critical value & $1 \%$ & $-4,374307$ \\
& & $5 \%$ & $-3,603202$ \\
& & $10 \%$ & $-3,238054$ \\
\hline
\end{tabular}

Sumber : Data sekunder BPS Diolah

MacKinnon value pada derajat kepercayaan $10 \%$ sebesar $(-3,238054)$, dengan nilai AIC minimum sebesar $(29,31618)$.

\section{Uji Kointegrasi}

Dua atau lebih variabel urut waktu yang tidak stasioner dikatakan terkointegrasi apabila masing-masing variabel tersebut memiliki pola trend yang sama. Ketika hal ini terjadi maka, apabila variabel-variabel tersebut diregres, trend di dalam masing-masing variabel akan menjadi saling menghilangkan. Hasil uji Kointegrasi variabel PDRB dan KK dengan membandingkan AIC minimum yang dihitung dengan rumus sebagai berikut:

$\mathrm{AIC}=-\frac{2 \mathrm{~L}}{\mathrm{~T}}+\frac{2 \mathrm{~K}}{\mathrm{~T}}$

dimana:

$\mathrm{L}=\log$ likehood,

$\mathrm{K}=$ banyaknya koefisien regresi kointegrasi,
$\mathrm{T}=$ banyaknya data pada regresi kointegrasi,

Hasil uji yang didapatkan adalah seperti yang dapat dilihat di tabel 4 dan 5 .

Berdasarkan tabel 4 tampak bahwa hasil uji kointegrasi dengan menggunakan uji ADF menunjukkan bahwa variabel PDRB dan KK terkointegrasi. Hal ini dapat dilihat dari nilai statistikl ADF yang lebih besar $(-3,8885)$ dibandingkan nilai kritis Mac Kinnon value pada derajat kepercayaan $10 \%$ sebesar $(-3,8030)$ dengan nilai AIC minimum sebesar $(36,665991)$ yaitu terdapat pada model III.

Berdasarkan tabel 5 tampak bahwa hasil uji kointegrasi dengan menggunakan uji ADF menunjukkan variabel KK dan PDRB tidak terkointegasi. Hal ini dapat dilihat dari nilai statistik ADF yang lebih kecil $(-0,3512)$ dibandingkan nilai kritis MacKinnon value pada derajat kepercayaan $10 \%$ sebesar (3,8030) dengan nilai AIC minimum sebesar $(34,888583)$ terdapat di model III. 
Tabel 4. Hasil Analisis Kointegrasi PDRB dan KK

\begin{tabular}{clrr}
\hline ADF Model I & & & \\
AIC = 36,798366 & Dickey Fuller t-statistik & & $-3,4759$ \\
& MacKinnon critical value & $1 \%$ & $-4,3912$ \\
& & $5 \%$ & $-3,6019$ \\
& & $10 \%$ & $-3,2257$ \\
\hline ADF Model II & & & \\
AIC = 36,798336 & Dickey Fuller t-statistik & & $-3,4759$ \\
& MacKinnon critical value & $1 \%$ & $-4,3912$ \\
& & $5 \%$ & $-3,6019$ \\
& & $10 \%$ & $-3,2257$ \\
\hline ADF Model III & & & \\
AIC = 36,665991 & Dickey Fuller t-statistik & & $-3,8885$ \\
& MacKinnon critical value & $1 \%$ & $-5,0328$ \\
& & $5 \%$ & $-4,1996$ \\
& & $10 \%$ & $-3,8030$ \\
\hline
\end{tabular}

Sumber : Data sekunder BPS diolah

Tabel 5. Hasil Analisis Kointegrasi KK dan PDRB

\begin{tabular}{llcr}
\hline ADF Model I & & & \\
AIC = 35,559075 & Dickey Fuller t-statistik & & 1,1320 \\
& MacKinnon critical value & $1 \%$ & $-4,3912$ \\
& & $5 \%$ & $-3,6019$ \\
& & $10 \%$ & $-3,2257$ \\
\hline ADF Model II & & & \\
AIC = 35,559075 & Dickey Fuller t-statistik & & 1,1320 \\
& MacKinnon critical value & $1 \%$ & $-4,3912$ \\
& & $5 \%$ & $-3,6019$ \\
& & $10 \%$ & $-3,2257$ \\
\hline ADF Model III & & & \\
AIC = 34,888583 & Dickey Fuller t-statistik & & $-0,3512$ \\
& MacKinnon critical value & $1 \%$ & $-5,0328$ \\
& & $5 \%$ & $-4,1996$ \\
& & $10 \%$ & $-3,8030$ \\
\hline
\end{tabular}

Sumber: Data sekunder BPS Diolah

\section{Uji Derajat Integrasi}

Uji derajat integrasi perlu dilakukan untuk penstasioneran data agar diperoleh regresi yang tidak lancung. Penstasioneran data Produk Domestik Regional Bruto (PDRB) dan Kesempatan Kerja (KK) dilakukan dengan melakukan uji ADF pada perbedaan tingkat satu atau derajat integrasi satu. Adapun hasil uji derajat integrasi variabel PDRB dan KK ditunjukkan oleh tabel 6 dan 7.

Dari tabel 6 tampak bahwa hasil uji derajat integrasi dengan menggunakan uji ADF terhadap variabel PDRB menunjukkan bahwa variabel PDRB tidak stasioner. Dera- 
Tabel 6. Hasil Uji ADF Variabel PDRB

\begin{tabular}{llrr}
\hline ADF Model I & & & \\
AIC = 33,29983 & Dickey Fuller t-statistik & & 3,370907 \\
& MacKinnon critical value & $1 \%$ & $-2,699769$ \\
& & $5 \%$ & $-1,961409$ \\
& & $10 \%$ & $-1,606610$ \\
\hline ADF Model II & & & \\
AIC = 33,34639 & Dickey Fuller t-statistik & & 2,888301 \\
& MacKinnon critical value & $1 \%$ & $-3,857386$ \\
& & $5 \%$ & $-3,040391$ \\
& & $10 \%$ & $-2,660551$ \\
\hline ADF Model III & & & \\
AIC = 33,04254 & Dickey Fuller t-statistik & & $-2,978640$ \\
& MacKinnon critical value & $1 \%$ & $-4,394309$ \\
& & $5 \%$ & $-3,612199$ \\
& & $10 \%$ & $-3,243079$ \\
\hline
\end{tabular}

Sumber: Data sekunder BPS diolah

Tabel 7. Hasil Uji ADF Variabel KK

\begin{tabular}{llcl}
\hline ADF Model I & & & \\
AIC = 29,10451 & Dickey Fuller t-statistik & $-0,969939$ \\
& MacKinnon critical value & $1 \%$ & $-2,679735$ \\
& & $5 \%$ & $-1,958088$ \\
& & $10 \%$ & $-1,607830$ \\
\hline ADF Model II & & & \\
AIC = 29,36353 & Dickey Fuller t-statistik & \multicolumn{3}{r}{} & $-7,766775$ \\
& MacKinnon critical value & $1 \%$ & $-3,737853$ \\
& & $5 \%$ & $-2,991878$ \\
& & $10 \%$ & $-2,635542$ \\
\hline ADF Model III & & \multicolumn{3}{r}{$-7,819534$} \\
AIC = 29,40220 & Dickey Fuller t-statistik & $1 \%$ & $-4,394309$ \\
& MacKinnon critical value & $5 \%$ & $-3,612199$ \\
& & $10 \%$ & $-3,243079$ \\
\hline
\end{tabular}

Sumber: Data sekunder Sekunder yang diolah

jat integrasi variabel PDRB diperkuat pada model uji terbaik yang mempunyai nilai Akaike Information Criterion (AIC) minimum. Hal ini ditunjukkan di model III dengan nilai ADF lebih kecil $(-2,978640)$ dibandingkan nilai kritis MacKinnon value pada derajat kepercayaan $10 \%$ sebesar $(-3,243079)$, dengan nilai AIC minimum sebesar $(33,04254)$.
Dari tabel 7 tampak bahwa hasil uji derajat integrasi dengan menggunakan uji ADF terhadap variabel $\mathrm{KK}$ menunjukkan bahwa variabel KK tidak stasioner. Derajat integrasi variabel KK diperkuat pada model uji terbaik yaitu pada uji yang mempunyai nilai Akaike Information criterion (AIC) minimum. Hal ini ditunjukkan di model I dengan nilai ADF lebih kecil yaitu sebesar 
$(-0,969939)$ dibandingkan nilai kritis MacKinnon value pada derajat kepercayaan $10 \%$ sebesar $(-1,607830)$ dengan nilai AIC minmum sebesar $(29,10451)$.

\section{Uji Kausalitas Granger}

Uji Kausalitas Granger yaitu merupakan sebuah metode analisis untuk mengetahui hubungan di mana di satu sisi suatu variabel dependen dapat dipengaruhi oleh variabel lain (variabel independen) dan di sisi lain varibel independen tersebut dapat menempati posisi variabel dependen. Hubungan seperti ini sering disebut sebagai hubungan kawal atau hubungan timbal balik.

Berdasarkan tabel 8 dapat dilihat bahwa hasil simulasi olah data dengan prosedur langkah pentahapan -LAG 5, LAG 6, dan LAG 7 menunjukkan hubungan kausalitas satu arah yaitu Produk Domestik Regional Bruto (PDRB) mempengaruhi Kesempatan Kerja (KK). Hal ini ditunjukkan dari nilai probabilitas Produk Domestik Regional Bruto (PDRB) mempengaruhi Kesempatan Kerja (KK) lebih kecil dari $\alpha=0,1$.

Penghitungan hasil simulasi olah data dalam penelitian ini adalah; terdapat pola hubungan satu arah yaitu antara PDRB dan Kesempatan Kerja di Propinsi Dati I Jawa Tengah. Artinya, bahwa kesempatan kerja di Propinsi Dati I Jawa Tengah selama hasil penelitian tidak menyebabkan peningkatan PDRB, tetapi justru sebaliknya meningkatnya PDRB akan dapat mendorong penciptaan kesempatan Kerja.

Tabel 8. Hasil Uji Kausalitas Granger Variabel PDRB dan KK

\begin{tabular}{cccc}
\hline Lag & \multicolumn{1}{c}{ Null Hypothesis } & F-statistic & Probability \\
\hline 1 & PDRB does not Granger Cause KK & 0,91071 & 0,35030 \\
& KK does not Granger Cause PDRB & 2,07776 & 0,16354 \\
2 & PDRB does not Granger Cause KK & 0,38477 & 0,68579 \\
& KK does not Granger Cause PDRB & 0,92047 & 0,41538 \\
\multirow{2}{*}{3} & PDRB does not Granger Cause KK & 1,89728 & 0,17077 \\
& KK does not Granger Cause PDRB & 1,11692 & 0,37150 \\
4 & PDRB does not Granger Cause KK & 1,51840 & 0,25406 \\
& KK does not Granger Cause PDRB & 0,63224 & 0,64829 \\
5 & PDRB does not Granger Cause KK & 4,74983 & 0,01753 \\
& KK does not Granger Cause PDRB & 0,59327 & 0,70629 \\
6 & PDRB does not Granger Cause KK & 7,05108 & 0,01057 \\
& KK does not Granger Cause PDRB & 0,28477 & 0,92648 \\
7 & PDRB does not Granger Cause KK & 6,16598 & 0,04902 \\
& KK does not Granger Cause PDRB & 2,33382 & 0,21554 \\
\multirow{2}{*}{8} & PDRB does not Granger Cause KK & 2,80635 & 0,43295 \\
& KK does not Granger Cause PDRB & 14,8543 & 0,19817 \\
\hline
\end{tabular}

Sumber: Data sekunder BPS diolah 


\section{SIMPULAN}

Simpulan hasil penelitian dengan uji kausalitas Granger tentang Produk Domestik Regional Bruto dan Kesempatan Kerja, ini adalah:

- Uji Stasioneritas

Pada uji stasioneritas dengan menggunakan metode Augmented Dickey Fuller (ADF) menunjukkan variabel PDRB stasioner, yang ditunjukkan oleh nilai t-statistik ADF PDRB sebesar 3,337178 lebih besar dari nilai kritis MacKinnon 10\% sebesar $-3,277364$.

Sedangkan uji stasioner dengan menggunakan metode Augmented Dickey Fuller (ADF) untuk variabel KK tersebut tidak stasioner. Hal ini ditunjukkan oleh nilai t-statistik ADF KK sebesar $-2,837492$ lebih kecil dari nilai kritis MacKinnon 10\% sebesar -3,238054.

- Uji Kointegrasi

Hasil pengolahan data menggunakan uji kointegrasi Augmented Dickey Fuller (ADF) menunjukkan bahwa variabel PDRB dan KK terkointegrasi. Ini dapat dilihat dari nilai t-statistik ADF PDRB dan KK yaitu -3,4759 lebih besar dari nilai kritis MacKinnon $10 \%$ sebesar $-3,2257$.

- Uji Derajat Integrasi

Dalam uji derajat integrasi menggunakan uji ADF menunjukkan variabel PDRB dan KK tidak stasioner. Hal ini dilihat dari nilai t-statistik variabel PDRB sebesar $-2,978640$ di bawah nilai kritis Mac Kinnon 10\% sebesar 3,243079 dan nilai tstatistik variabel KK -0,969939 di bawah nilai kritis MacKinnon $10 \%$ sebesar $-1,607830$.
- Uji Kausalitas Granger

Berdasarkan analisis uji kausalitas Granger diketahui terdapat hubungan kausalitas satu arah yaitu Produk Domestik Regional Bruto (PDRB) mempengaruhi Kesempatan Kerja (KK). Hal ini ditunjukkan dari nilai probabilitas Produk Domestik Regional Bruto (PDRB) mempengaruhi Kesempatan Kerja (KK) lebih kecil dari $\alpha=0,1$.

Dari simpulan penelitian yang dilakukan, dapat diberikan saran sebagai pertimbangan bagi perencanaan pembangunan ekonomi daerah khususnya di Provinsi Dati I Jawa Tengah bahwa:

1. Pemerintah Daerah kiranya dapat mengupayakan dan menciptakan lapangan pekerjaan baru untuk dapat menambah tingkat kesempatan kerja.

2. Strategi kebijakan tingkat kesempatan kerja yang tertata dan selaras bagi daerah akan memberikan dampak positif untuk keberlanjutan pelaksanaan tujuan pembangunan ekonomi nasional.

3. Dilakukan suatu studi empiris lebih komprehensif dalam usaha untuk memperkuat basis-basis perekonomian daerah dan nasional dengan menjadikan tingkat kesempatan kerja sebagai suatu tolok ukur penting untuk dipertimbangkan bagi salah satu keberhasilan arah kestabilan ekonomi daerah dan nasional.

\section{DAFTAR PUSTAKA}

Arief Sritua, 1987, Metode Penelitian Ekonomi: Jakarta: Lembaga penerbitan Universitas Indonesia.

Arrow Kenneth. J, Michael. D. Intriligator, 1989, Handbook of Development Eco- 
nomics, Volume I, North-Holland: Elsevier Science Publishers.

B.Hirawan Susijati, 1992, Pembiayaan Pembangunan Daerah, dalam Prospek Ekonomi Indonesia Jangka Pendek Sumber Pembiayaan Pembangunan, Jakarta: FE-UI dan Gramedia Pustaka Utama.

Badan Pusat Statistik, beberapa tahun penerbitan, Jawa Tengah dalam Angka. Jawa Tengah: BPS.

Badan Pusat Statistik, beberapa tahun penerbitan, Statistik Indonesia, Jakarta: BPS.

Badan Pusat Statistik, beberapa tahun penerbitan, Statistik Jawa Tengah dalam Angka, Jawa Tengah: BPS.

Bank Indonesia, Indonesian Financial Statistics, Jakarta: BI.

Blanchard Oliver Jean and Stanley Fischer, 1989, Lecturer on Macroeconomic, Cambridge, Massachusetts, USA: The MIT Press.

BR. Arfida, 2003, Ekonomi Sumber Daya Manusia, Jakarta: Ghalia Indonesia.

Branson William.H, 1989, Macroeconomics Theory and Policy, Third Edition, New York: Harper Collins Publishers Inc.

Chenary Hollis et.al, 1989, Industrialization and Growth, Washington: World Bank.

Chenary Hollis, T.N. Srinivasan, 1989, Handbook of Development Economics, Volume II, North-Holland: Elsevier Science Publishers.

Daryanto Agus, 2001, Analisis Struktural Kesempatan Kerja di Indonesia: Sebelum dan Setelah Krisis Moneter, Jurnal Falsafah Sains Program Pasca Sarjana/S3 IPB, Juni 2001, Bogor.
Djajanegara Siti Oemijati dan Aris Ananta, 1986, Mutu Modal Manusia, Jakarta: Lembaga Demografi FE-UI,

Fergus Dwiantini Joyodipuro, Diah Widyawati, 1994, Tenaga Kerja dalam Pembangunan Berkelanjutan, Jakarta: Lembaga Demografi FE-UI.

Gujarati, Damodar, 1997, Dasar Ekonometrika, Jakarta: Penerbit Erlangga.

Gujarati, Damodar, 2003, Basic Econometrics, Fourth Edition, New York: Mc Graw-Hill.

Ikhsan Mohammad, 2005, Industri Manufaktur, Pertumbuhan Ekonomi dan Penyerapan Tenaga Kerja, Sidang leno ISEI XI, Jakarta.

Indrawati Sarastika, Daryono Soebagiyo, 2007, Analisis Uji Kausalitas Penerimaan Pajak dan Pengeluaran Pemerintah di Kota Surakarta dengan Menggunakan Motode Granger Tahun 20042003, Jurnal Ekonomi Pembangunan, Vol.7, No.2 Desember 2006, Balai Penelitian dan Pengembangan Ekonomi FE-UMS

Kompas Harian Umum, beberapa penerbitan, Kompas, Jakarta

Meier Gerald.M,1989, Leading Issues in Economics Development, Fifth Edition, New York: Oxford University Press.

Pindyck.R.S and D.L.Rubinfeld, 1990. Econometric Models and Econometric Forecasts, 4th.ed, New York: McGrawHill.

Republik Indonesia, beberapa tahun penerbitan, Nota Keuangan dan RAPBN, Jakarta: Republik Indonesia. 
Samuelson, Nordhaus, 2005, Economics, Eighteenth Edition, New York: Mc Graw-Hill.

Simanjuntak, Payaman J. 1985. Pembangunan Ekonomi Sumberdaya Manusia. Jakarta: BPFE UI.

Siregar, Arifin M. 1982. Sumberdaya Manusia, Kesempatan Kerja dan Pembangunan Ekonomi. Jakarta: FE UI.

Soebagiyo, Daryono, 1994, Analisis Hubungan Keuangan Pusat-Daerah terhadap Perkembangan Perekonomian Daerah di Indonesia, Tesis Magister in Economics Pascasarjana Universitas Indonesia, Tidak Dipublikasikan, Jakarta: Fakultas Pascasarjana Bidang Ilmu Ekonomi Universitas Indonesia.

Soebagiyo Daryono, Chuzaimah, Eni.S, 2003, Analisis Human Capital Propinsi Dati I Jawa Tengah, Tidak Dipublikasikan, Surakarta: Penelitian Pusat Studi Kependudukan Lemlit UMS.

Soebagiyo Daryono, Maulidyah, Chuzaimah, 2005, Analisis Pengaruh Kesempatan Kerja Tingkat Beban/Tanggungan dan Pendidikan terhadap Penganggguran di Propinsi Dati I Jawa Tengah, Tidak Dipublikasikan, Surakarta: Pusat Studi Kependudukan, Lemlit UMS,

Sukirno, Sadono. 2000. Makro Ekonomika Modern. Jakarta: PT. Raja Grafindo Persada.

Susanti Hera, Moh.Ikhsan, Widayanti, 1995, Indikator indikator Makroekonomi,
Lembaga Penerbit FE-UI dan LPEM FE-UI, Jakarta

Swasono, Yudo dan Endang Sulistyaningsih. 1983. Metode Perencanaan Tenaga Kerja Tingkat Nasional, Regional dan Perusahaan. Yogyakarta: BPFE UGM.

Tambunan Tulus TH, 2001, Perekonomian Indonesia, Jakarta: Ghalia Indonesia.

Team, 2000, Dasar dasar Demografi, Jakarta: BPFE-UI.

Tjiptoherijanto Prijono, 2004, Jaminnan Sosial Tenaga Kerja di Indonesia, Jurnal JSI Volume 9.1 Jakarta: Universitas Indonesia.

Todaro Michael.P,1989, Economics Development in The Third World, Fourth Edition, New York: Longman Group Ltd.

Widodo Suseno Triyanto, 1990, Indikator Ekonomi; Dasar perhitungan Perekonomian Indonesia, Jogjakarta: Penerbit Kanisius.

World Bank, 2001-2004, World Bank Population Publication, Washington DC. USA: World Bank.

Yudoko, 2007, Analisis Kausalitas antara Produk Domestik Regional Bruto (PDRB) dan Tingkat Kesempatan Kerja, Skripsi S1 Tidak Dipublikasikan, FE-UMS

Zellner, A., 1971, In Introduction to Bayesian Inference in Econometrics, New York: John Wiley \& Sons. 